\title{
Mapping intangibilities in creative tourism territories through tangible objects: a methodological approach for developing creative tourism offers
}

\section{mapear intangibilidades nos territórios de turismo criativo através de objetos tangíveis: uma metodologia para o desenvolvimento de ofertas de turismo criativo}

\author{
Sónia Moreira Cabeça \\ University of Algarve, CIEO - Research Centre for Spatial and Organizational Dynamics, Faro, Portugal \\ soniacabeca@hotmail.com \\ Alexandra Rodrigues Gonçalves \\ University of Algarve, ESGHT and CIEO - Research Centre for Spatial and Organizational Dynamics, Faro, Portugal \\ marodrig@ualg.pt \\ João Filipe Marques \\ University of Algarve, FE and CIEO - Research Centre for Spatial and Organizational Dynamics, Faro, Portugal, \\ jfmarq@ualg.pt \\ Mirian Tavares \\ University of Algarve, FCHS and CIAC - Research Centre in Arts and Communication, Faro, Portugal, \\ mtavares@ualg.pt
}

\begin{abstract}
What can people express about their places through the objects that they valorise and link to their territory? Can objects create narratives about a place's identity and collect significant cultural information that locate people in their places? Can such cultural mapping be a useful tool in the design of creative tourist offers?

The Project CREATOUR held a series of Idea Laboratories with several entities that provide creative tourism experiences, approaching cultural mapping through objects as a tool for regional actors to discover what is 'so special' about their places, a way to link tourism offers with the community where they take place.

These exercise lead participants to remark on the importance and idiosyncrasy of their regions and evidenced the importance of cultural mapping to a more sustainable offer and the overall marketing of destinations. Mapping intangibilities through tangible objects helped to capture what gives meaning to particular places.
\end{abstract}

Keywords: Cultural mapping, emotional and intangible cultural mapping, objects, creative tourism, CREATOUR Project.

\section{Resumo}

O que exprimem as comunidades sobre os lugares que habitam, através dos objetos que valorizam e associam ao território? Podem os objetos criar narrativas em torno da identidade de um lugar, situando as pessoas nos lugares em que vivem? Pode esta forma de mapeamento cultural ser uma ferramenta útil no desenho de ofertas de turismo criativo?

O Projeto CREATOUR realizou uma série de Laboratórios de Ideias com várias entidades que oferecem experiências de turismo criativo, nas quais utilizou a técnica do mapeamento cultural através de objetos, enquanto ferramenta para os atores regionais descobrirem o que torna os seus lugares 'tão especiais', vinculando as ofertas de turismo à comunidade onde elas ocorrem.

Este exercício levou os participantes a refletirem sobre o valor e as idiossincrasias das suas regiões e evidenciou a importância do mapeamento cultural para uma oferta mais sustentável e para a comercialização de destinos criativos. Mapear intangibilidades através de objetos tangíveis permitiu apreender os significados de cada lugar.

Palavras-chave: Mapeamento cultural, mapeamento cultural emocional e intangível, objetos, turismo criativo, Projeto CREATOUR.

\section{Cultural mapping: the interpretation of space}

A place's identity is a narrative built upon the meanings that people assign to it based on its physical, social, and historical dimensions (Eräranta, Leino, Seppälä, Viña, \& Timonen, 2016). Given that identity, 'ordinary people and communities can make maps to express the stories about their lives and home places' (Lydon, 2003, p. 131). To trace, acknowledge, and place cultural assets, therefore, is a powerful instrument to communities. Making the intangible visible, cultural mapping collects significant cultural information, traditions, stories, values, and expectations that locate people in their places, and in the world-at-large. It is also a powerful governance mechanism, involving communities in a bottom-up process of actively determining a place's identity. Place-based and involving a participatory interaction, cultural mapping promotes social cohesion and is thus a 'first step in a longer journey toward cultural sustainability' (Jeannotte, 2016, p. 41).

Cultural mapping may be defined as a 'process of collecting, recording, analysing and synthesising information in order to describe the cultural resources, networks, links and patterns of usage of a given community or group' (Stewart, 2007, p. 8), providing 'an integrated picture of the cultural character, significance, and workings of a place' (Pillai, 2013, p. 153). Mapping is also an interpretation of a space, involving not only the work of collecting information, but also of transposing the data into a visual form through cartographic processes. To map 
is to construct a visual narrative about a place's identity, through the community's and groups' eyes.

Today, modern cartography recognises maps as memory holders and, as well the importance of integrating emotional and affective dimensions in maps (Caquard \& Cartwright, 2014). It also recognises the need to include a cultural perspective in the process of mapping (Cosgrove, 2005). As Perkins (2009) points out, a broader set of cartographic practices are needed, linking geography to the social context. Emotions and perceptions are 'a crucial part of modern cartography' (Pánek \& Benediktsson, 2017, p. 71). Altogether, the scope of cultural mapping is growing wider.

The main questions on cultural mapping - what to map? how to map it? - lead us to think about cultural mapping as both a methodology and a process (and a theory generator, according to Kitchin, 2010). Cultural mapping involves the use of the appropriate forms of collection and presentation of data to convey its intended meanings. A social process anchoring identity in place also occurs while mapping (Offen, 2003). Participatory mapping 'inherently critique[s] the dominant, or conventional, historical geography', and discusses 'the larger social and political meaning of the mapping project' (ibid). As Ortega Nuere \& Bayón (2015) observe, cultural mapping gathers information but detects gaps as well. As a process, cultural mapping is a participatory planning (Duxbury, GarrettPetts, \& Maclennan, 2015), and a development tool (Freitas, 2016) available to local communities. 'Community mapping is both the recovery and discovery of the connections and common ground that all communities share', and a vital element 'for participatory learning, community empowerment and sustainable planning' (Lydon, 2003, p. 131).

Duxbury, Garrett-Petts, \& Maclennan (2015) identify five main trajectories in cultural mapping practice nowadays. The first, 'community empowerment' or 'counter-mapping', creates alternative maps, with alternative views that tend to seek a change of perspective. The second, 'cultural policy', seeks to bring together all sectors of a given community (civil, academic, industry, government) towards the development of cultural and creative sectors. The third, cultural mapping in the context of municipal governance, concerns the cultural planning undertaken by local governments in order to know and improve their cultural assets. Artists also involve themselves in cultural mapping (fourth trajectory), inspired by issues such as urbanisation or cultural practices. Finally, the academic world, in theory and practice, approaches questions such as map production, intangible and emotional mapping, recartographisation, geographical information systems, etc.

Today, new ways of mapping and counter-mapping drive us to question mapping beyond such standardised procedures (Cattoor \& Perkins, 2014) and to go beyond the boundaries of geography. The narrative power of maps and the recognition that a place's identity is constructed of the meanings that people give it (Eräranta et al., 2016) is leading to new epistemological questions and new theoretical approaches such as Kitchin, Gleeson, \& Dodge's 'post-representational cartography' (2013), Anderson \& Smith's 'emotional geographies' (2001), Austin's 'cognitive mapping' (1994) (in Graybill, 2013), Graybill's 'emotional topography' (2013), or Aitken \& Craine's 'affective geovisualisation' (2006). Maps, on these views, not only represent space but also what draws us emotionally (Craine \& Aitken, 2009); thus, our emotional responses to cartography (cognitive cartography) must be considered (Klettner, Huang, Schmidt, \& Gartner, 2013).

Cartography has become a form of communication used by the general public, providing 'volunteered geographical information' (VGI - or 'user-generated content' (UGC): content produced by average users) (Goodchild, 2007) that might enable the study of how people experience and make sense of things (Straumann, Çöltekin, \& Andrienko, 2014; Chua, Servillo, Marcheggiani, \& Moere, 2016) and lead us to rethink the relationship between human users/consumers and digital cartographic information (Craine \& Aitken, 2009). With sophisticated geovisualisation, 'visual technologies probe and explore the depths of data, creating new ways to think spatially' (ibid: 149). New maps are conceived, with new shapes, with different content, focusing intangible heritage, emotional responses, stories, etc., and providing alternative maps in which landscape is reimagined (recartographisation) with new narratives and new discourses, challenging the dominant views (counter-mapping). Mapping methodologies are broader as new theoretical frames are discussed, and cartography readjusts to enfold intangible, emotional, social and cultural aspects. Examples of cultural mapping methods include mapping tourist maps (Farías, 2011); the spatial structures of stories (Caquard \& Cartwright, 2014); story-telling (Jeannotte, 2016), writing-as-mapping (Radović, 2016); mapping-aswayfinding (Roberts, 2014); filming while walking (cinemapping) or other wayfinding practices such as wandering (Radović, 2016); screenplay, screenwriting and scenography (Eräranta et al., 2016); ethnographic studies (Cauchi-Santoro, 2016); and mapping web user's photographs (Straumann et al., 2014). Some of these approaches combine new methodologies with the most advanced GIS (geographic information system) techniques, geovisualisation techniques and tools (Craine \& Aitken, 2009), new software, and new ways of approaching data (distortions, algorithms, variable map-scales... (Reuschel, Piatti, \& Hurni, 2014)). Nonconventional maps and modern cartography are reimagining landscapes and integrating emotional and affective dimensions in maps, reconceiving spaces, mapping stories and studying ways to represent emotions - often using social media to convey these ideas.

\section{Cultural mapping in creative tourism}

When approaching creative tourism, the potential of cultural mapping is immediately apprehensible. Creative tourism is 'tourism which offers visitors the opportunity to develop their creative potential through active participation in courses and learning experiences which are characteristic of the holiday 
destination where they are undertaken' (Richards \& Raymond, 2000, p. 18). It is also a sustainable tourism: 'Creative tourism is travel directed toward an engaged and authentic experience, with participative learning in the arts, heritage, or special character of a place, and it provides a connection with those who reside in this place and create this living culture' (UNESCO, 2006, p. 3). As the organisation states, tourism is helping to revitalise local economies.

Focusing on the privileged relationship between tourists (visitors/guests) and locals (visited/hosts), creative tourism presupposes an exchange of experiences, knowledge and skills, as well as tourists' engagement in events that also involve the communities. By creating connections between the different types of participants, creative tourism bonds people to places, promoting tourist immersion into the local culture and the active participation in cultural and creative activities. In such a tourism experience, the place of destination asks to be seen as more than surroundings (Graybill, 2013), a catalogue or an attraction.

Destination, as a perceptual concept (Buhalis, 2000), is subjectively interpreted by visitors, taking into account what they most value (culture, education, itinerary, purpose) (ibid.). At the end of the last century, Jensen (1999) noted that the emotional and symbolic aspects of products were being valued by consumers. In such a 'dream society' (ibid.), ethics, spirituality and authenticity (Guerreiro \& Marques, 2017) count when making a choice, and products are valued by considering the history they tell, their symbolism, the emotions they raise, how they make the consumer feel. In fact, most recent studies (Gu \& Ryan, 2008; Ilincic, 2013) indicate that tourists can cognitively, affectively, and socially benefit from their tourism experiences and, further, develop emotional links with the places visited. In creative tourism, creative and symbolic capitals, nowadays, is a key element, with tourists' increasing demand for 'engaging experiences' (Richards, 2016). Travelling to a different place is an opportunity to develop new experiences and for self-learning (Gonçalves, 2005).

On the other hand, when tourism products integrate local communities in their planning (a key to sustainable tourism), economic, environmental, socio-cultural benefits can be achieved (Simpson, 2008). When involved in hosting and determining what is so special about their places, communities feel 'special by living in a special place' (Gu \& Ryan, 2008, p. 646). Therefore, the local economy improves beyond the profits from tourism (Ohridska-Olson \& Ivanov, 2010). In this paper, the 'Ohridska-Olson's creative tourism business model' envisions prosperity for the local community, identifying possible benefits that are place-based such as cultural heritage and cultural values preservation, local identity, pride, local culture, etc. Tourists' demand is also place-based: they seek, in the place of their destination, authenticity, human interaction, cultural immersion, unique local cultural offerings, arts and crafts, and the like (ibid.).
Benefits may also come from involving communities in cultural mapping, as mentioned above. As Grasseni (2004) points out, mapping - by evoking history and cultural practices - shapes local identities. Several works (Lydon, 2003; Offen, 2003; Parker, 2006; Perkins, 2007) focus on community building through cultural mapping emphasising, as said before, the achieved bond between people and places and the 'common ground that all communities share' (Lydon, 2003, p. 131).

Tourism impacts upon attachment to a place are visible (Gu \& Ryan, 2008, p. 645). Creative tourism is deeply linked to the territory and to how each place is felt. Topophilia, the emotional attachment to place (Casey, 2009), makes us consider cultural mapping - particularly emotional and intangible cultural mapping - a useful tool in the design of creative tourist offers, a means to understand what best describes a tourism destination. Creative tourism takes into account what is so special about the place, ensuring the involvement of communities and tourists, as may contribute to a more sustainable development and economic and social income for communities, and regions.

\section{The CREATOUR experience}

In Portugal, Project CREATOUR: Creative Tourism Destination Development in Small Cities and Rural Areas, a multidisciplinary research and incubation project, is serving to connect the cultural, creative and tourist sectors. In an integrated approach, providing both research and the development of creative tourism experiences, the project undertaken by five Portuguese universities, aims to boost creative tourism in small towns and rural areas of Portugal, creating a diversified offer; valuing skills, knowledge, practices and creative paths and establishing lasting relationships among various entities.

By the end of 2016, CREATOUR opened a call to every type of organisation, entity and professional working in Portugal (Norte, Centro, Alentejo, and Algarve) willing to implement and develop creative tourism initiatives and collaborate with the CREATOUR research team.

Twenty pilot projects were selected (five in each region) from one hundred and thirty-eight online applications. In the online form, applicants had to describe the proposed activities, indicating their location and connection to the territory involved (i.e. what makes the place special, interesting or inspiring, and whether it is already visited by tourists). They also had to ensure an adequate means for the proper functioning of the activities, indicating their experience in the area of tourism and existing partnerships and presenting a biographical note of the promoter. Information about the target audience, i.e. how could activities boost participant's creativity and involve them in a learning process, were also key aspects to be addressed. Twenty pilot cases were selected, taking into account the proposal's cultural value, creative nature, and diversity; their capacity to capture tourists' interest; community benefits, and their willingness to work with the members of the project. 
Since 2017 and for the next two years (2017-2019) these twenty organisations, in collaboration with CREATOUR, will develop creative tourism pilot initiatives and participate in workshops functioning as laboratories of ideas. In 2018, other twenty pilots joined this network. With these creative tourism offers, the project and its partners aim to guarantee the initiatives' sustainability and to contribute to local development processes, focusing on local cultural resources and community involvement. Pilot initiatives such as this aim to revitalise traditional arts and crafts; promote spaces and places; evoke memories; foster creativity and the arts; develop technologies; and present the natural, historical, cultural heritage of regions. Offers include cooking and traditional culture, visual culture, design, illustration, photography, crafts, technology, nature and walking routes. Visitors have had the opportunity to have cooking classes, learn a traditional craftsmanship or know-how, discover the territory through new technology, improve their skills in different areas, participate in co-creation processes and community-art, interact and work along with local community, develop artistic skills (art, theater, dance, music, sculpture), follow thematic routes, attend to workshops (weaving, clay, wicker, photography). More than just see or taste, the opportunities have enabled participants to make, learn and emerge in the creative experience. Such a network, if strengthened, will diversify tourist offerings, attract new tourists, break seasonality in tourism and bring tourists to small towns and rural areas where tourism has not yet been developed.

Committed to supporting the development of specific content and skills that can help to create a more sustainable offer, CREATOUR performed a series of regional IdeaLabs., laboratories of ideas carried out with the selected pilots working in partnership with the project. As stated, these first regional laboratories were developed by region, working with the five pilots from each. In IdeaLabs., the accepted creative tourism initiatives were worked and the ideas, such that they could be practically implemented. The goal of the project was to trigger creativity; support content development; readjust, present and discuss pilot initiatives; exchange experience and knowledge; and create synergies. Linking creativity to a given place and the surrounding territory and involving the partners and their projects in their communities was a key exercise. By connecting the creative activities to their place of implementation and placing them, significant cultural assets both tangible and intangible - begin to emerge, thereby determining the identity of the place. This is an important exercise, considering that creative tourism, in and of itself, seeks to be a culturally-based and sustainable enterprise.

Cultural mapping has been thought to be an adjusted methodology to make people think about their places and what makes them so special. Therefore, before Idea Labs., pilots were asked to bring a 'basket full of ideas' (twelve objects that characterise the region or the community where the proposed initiative was going to be implemented), two regional maps, and pictures of some activities of the project. CREATOUR asked the pilots to bring something photographic, sweet, creative, fragrant, historical, relaxing, symbolic, traditional, thrilling, musical, authentic, innovative.

Attachment to objects is a well-known phenomenon; their importance in expressing social relations and feelings has long been documented, namely in the famous work of Marx, 'Capital' (1867). Objects express and link us to ourselves and to the world. Workers were paid due to their labour power, their capacity to produce. Paying work by work, objects, and the relationship between the producer and the product of his/her work is concrete; when the latter becomes a purely exchangeable symbol, commodity separates the labour from its value. By separating the forces of production from labour and the producers from the objects that are their work product; the commodity, disconnected from the social relations that produced it, finds its origins erased. The social conditions of production end up expressing this separation - or, in Marx's terms, alienation between the worker and his/her work. Objects, on the other hand, enchant, have a mana (Mauss, 1988). Objects can be invested of forces, spirits, and magical properties through the relation that the subjects establish with them (ibid.). They have not, by themselves, a supernatural power: it is what they represent that valorises them beyond their venal value (Mauss, 1988, p. 185). Magic is not in objects, but rather in the relations that we establish with them (Mauss, 1971, p. 132). Put simply, magic in what objects evoke within us.

So, what can people express about their places through the objects that they valorise and link to their territory's idiosyncrasies?

Pilots answered with creative solutions, bringing together different types of baskets and objects. Several different objects helped them contextualise who they are, what makes their places so special, what they want to share with tourists, which truly represents a territory. While presenting the objects that identify their territory, one by one, to the audience, each pilot approached the initiatives to be implemented and framed their presentation within the territorial context. Objects were the intermediate between activities and territories, a simpler way to contextualise actions. Useful to pilots, once the pilots considered their territory as a tourism offering/product; the listeners were better able to understand the information provided. Objects were the tool to communicate identity. As Crang stated, 'the process of envisioning is part of the way people understand the world' (1997, p. 370).

IdeaLabs excelled in food: cakes, traditional delicatessen, sweets, fruits (oranges and lemons), cheese, and also olive oil, seeds, and aromatic herbs. Pilots brought raw material and other objects to be used in their experiences: marble, mosaics, clay pieces, salt, a cataplana (type of casserole). Traditional handicraft was also presented in many tables: cloths, mantles, embroidery, statuary, crockery. Also, photographs and postcards evoking memories: people who are gone, landscapes 
dramatically changed, etc. Brochures and books; music (CD) and musical instruments from the particular region were displayed. Although cultural objects closely associated with local traditions were in the majority (along with several papers), nature was not forgotten; some pilots brought rocks, plants, and even a bottle of air. While presenting the objects and the projects, 'place', 'territory', 'creation', 'community', 'artists', 'experience', 'participants', 'culture', 'tourism', and 'gastronomy', were some of the most common words.

Objects were defined and referred using words such as 'culture', 'memory', 'innovation', 'integration', 'creativity', 'will', 'endurance', 'people', 'project', 'reinvention', 'soul', 'earth', and 'involvement'. Objects, thus, fulfilled their evocative and mediatory functions.

These words were also used afterwards, while circling the object's exhibition. After presentations, objects were displayed on tables, one per pilot. All participants then had the opportunity to take a further look, to see, touch, taste, and feel the presented objects. A conversation on these objects was inescapable. Which objects draw the most attention? Which one was liked the most and why? What was innovative? What did we like most at each table? Which of these objects make us feel and what do they remind us of? This circle of objects gave way to interactions amongst all participants, the CREATOUR team and project members included, providing 'inspiring readings' that generated symbols and meanings, as one participant observed.

The presentation of the projects, focusing on the themes described above through objects, also meets the pilot's objectives in developing creative tourism initiatives: create value from the territories and people's identity resources, generate territorial attractiveness, boost a sustainable social and territorial development that integrates nature and places, safeguard and promote cultural identities, 'work the collective' by reinforcing community, enhance crafts and give financial support to craftsmen, develop local economy, and generate affection between visitors and communities.

The exercise was also a first start to summarising important issues in the differentiation process of each tourism offering and with regard to the need for territorial and community support. This session was followed by group dynamics intended to generate new ideas. Afterwards, with a new contextualisation (tourism offers placed within the relevant territory) and new ideas, pilots were invited to present their business model, contemplating several aspects: implementation, objectives, target audience, partners, value proposition, marketing, resources, costs, revenues and creative tourism actions. The exercise benefitted from cultural mapping; as well, with a better understanding of the 'spirit of the place', the business plans did not fail to embrace the identity elements of each region / community / offer. This finding, along with the results of the surveys, indicated that pilots benefitted from cultural mapping. CREATOUR intends, therefore, to devote more time to objects.

\section{Major findings and conclusions}

A questionnaire, a source of original data collection, was administered at the end of each regional IdeaLab, to evaluate the sessions and improve further workshops. Questions were intended to assess (on a scale ranging from absolutely disagreeing to absolutely agreeing) the importance / utility of IdeaLabs in relation to aspects such as providing useful information and developing partnerships as well as personal knowledge, new ideas, and action plan development. It was also intended to assess, on a scale from dispensable to indispensable, the relevance of each session (presentation of the project and of creative tourism, presentation of the pilot projects and cultural mapping, synergy session, thinking initiatives, testing the potential of initiatives, developing an activity plan and presenting it...) and acknowledging the more and less positive aspects and the insufficient, sufficient, and excessive ones. Respondents were also asked to select all the phrases that applied to their experience: 'IdeaLab has changed my idea considerably', 'It was an indispensable step for the implementation of the experience', 'I'm willing to participate in the next IdeaLab', 'I'm more eager to start a creative tourism experience', 'I met potential partners', 'I learned more about creativity, culture and tourism', 'I know what I want to do', '। know how to develop the initiatives I proposing'.

Data from the analysis of the questionnaires indicate that the session devoted to the presentation of the cultural and creative tourism experiences was stated as the most relevant session. In fact, $83 \%$ of the participants thought the presentation 'imperative', while others found it 'important'. This session was never seen as 'less important' or 'unnecessary'. Cultural mapping was never considered to be an excessive aspect of the event, either. Yet, some participants would have liked to have more time to map and discuss mapping.

'To know and to be known' was one of the most valued aspects of the event. When asked to point out the most positive aspects of the event, most pilots focused on 'sharing of experiences and working in partnership', 'interaction between the elements of the CREATOUR project and the other participants' and 'transfer of knowledge between the parts involved'. The first two considerations were also less pointed to as negative aspects (the first was not even mentioned amongst pilots). Evaluation showed that the regional IdeaLabs. have fostered relationships that might lead to new partnerships. This actually, was the more referred impact of the events: 'I met potential partners'. Also, pilots stated their willingness to start a creative tourism experience. They knew what they wanted to do. While evaluating the importance / utility of the IdeaLabs, pilots agreed that such an event allowed them 'to meet and communicate with the other participants', 'to start establishing partnerships' and 'to learn and to know different points of view'. 
Regional IdeaLabs, with the promotion of relationships between their partners, had the greatest success. Cultural mapping was crucial to this result. Objects were revealed to be important for contextualising the regions, communicating the intended initiatives, and boosting interactions. If something emerged as a common element, transverse to all regional IdeaLabs., it was this idea that held sway: objects map, link, explain, promote interaction and are an effective way to communicate, to give information, to let know interests and ideas.

The data confirm that cultural mapping helped to strengthen the CREATOUR network. As D'Angella \& Go (2009) stated, 'in tourism destinations collectivism is needed for individual success' and cooperation is a 'win-win situation' that 'brings higher competitiveness for the actors involved' (p. 437). In their article, the authors approach an important outcome of this notion of 'social inclusion': jointly carrying out activities, its seasonality was found to decrease. Creative experiences are seen as a response to that same challenge, i.e. by diversifying tourism offers and attracting new visitors. Therefore, CREATOUR is highly committed to developing its partners' relations and converging goals and strategies. In fact, a special decision factor in the process of choosing the twenty pilots that reinforced the network in 2018 was, precisely, their capacity to complement and respond to strengthening the existing pilot network and projects, thereby protecting it from competition. Plus, a joint strategy and the development of strong relations amongst all will aid in marketing 'a destination that should balance the strategic objectives of all stakeholders as well the sustainability of local resources' (Buhalis, 2000, p. 97). Sustainability is achieved by taking into account places and identities; the use of local resources (human, natural, cultural, social) can bring benefits for the region. Cultural mapping can be an important tool not only to trace such assets, but also to involve participants in cooperative actions. Pilots must also be involved with the community and local stakeholders. The CREATOUR network must also be strengthened by other formal and informal partnerships, involving decision makers, as D'\&G predict. In such a network, the use of all social capital might enable the management of all the elements that make up a destination (attractions, access, marketing, human resources, image and pricing) (ibid.). That can impact both the structuring of the creative tourism offer and its promotion and results. Given the positive aspects of an integrated approach in creative tourism, the research team established contacts with the institutions that represent, promote and value tourism, have sustainable partnerships and long lasting relation with other associations, companies, people involved in tourism (associations with a vast number of associates such as ATA - Algarve Tourism Bureau, and public bodies such as RTA Algarve Tourism Region).

The cultural mapping exercise, its outcomes, and the evaluation report indicate how important it can be to acknowledge and trace the cultural assets of a given community. Indeed, each community, in its creative initiatives, must be involved. Creative destinies create distinctive identities. Moving from tangible to intangible cultural resources (Richards, 2011), creativity can be used to implement creative tourism as a tourist activity or as a backdrop for tourism. That involves either active involvement of tourists in the creative activities of the places they visit, either placing themselves in the creative environment they are in. Tourist creates or is inspired. So, in creative tourism, to map emotions, 'what does it feel like?' is central.

Intangible and emotional mapping is being further used to collect different perceptions of the urban space (EmoMap Project), to build maps that capture how people feel about a city (Invisible City Project), to map the affective, sensual, and ephemeral complexity of spaces, focusing on intangible 'subtleties' (Mn'M Project - Measuring the Non-Measurable), to map the culture and the expressions of places (Small Cities CURA). The same exercise is being applied to literature, in the Literary Atlas of Europe, a project that maps and analyses the geography of fiction. These different applications of the same resource (providing educational, social, community, and academic tools) seem to coincide in one aspect: the statement of local identities through a place's significance. Emotional links can be created through cultural mapping. Understanding the emotional impact of territories, and which emotions arise while participating in local creative activities, can help us draw an emotional landscape that serves to link both communities and visitors to the places. Such 'emoscapes' could be an interesting tool to communicate tourism offers in small cities and rural areas and serve as a useful marketing resource.

In the nearest IdeaLabs. the session devoted to objects will be larger, given the pilots expectations and needs, and the results of the first exercise. To visualise and contextualise objects is an important first approach to improving creative tourism initiates and a first start towards partnerships. It would be useful, though, to make the objects exhibit last in images and in the memory of all participants. A document presenting all items would be useful; this could serve as an intangible and emotional map. Several methodologies and tools could be considered. Some images were preserved through photographs, some included in the Instant Report documenting each IdeaLabs.

By asking CREATOUR pilots to remark on the importance and idiosyncrasy of their regions through objects, the participants managed to create an emotional narrative about them. 'The simple location of the events alone is not sufficient to grasp the meaning associated with place' (Pearce, 2014, p. 102). Emotions, spaces and places are very much connected (Pánek \& Benediktsson, 2017), so intangibilities are an important part of a place's identity, as are 'aspects that provide a "sense of place» and identity to specific locales, and the ways in which those meanings and values may be grounded in embodied experiences' (Longley \& Duxbury, 2016, p. 2). As a result of mapping intangibilities through tangible objects, pilots found or rediscovered their regions' identity, something they could use to create sustainable offers to tourists. They captured 'narratives that give meaning to a particular place' (Jeannotte, 2016, p. 41). 
Tourism and culture play an important role in the construction of the landscape, the destiny's image (Gonçalves, 2005). Creative tourism, as a cultural offer, is deeply rooted in places and territorial conditions; it is place-based. There is a spatial dimension of creativity that relates to specific features of territorial capital (natural, physical, symbolic, human and spatial) (Barata, Molinari, Marsh, \& Cabeça, 2017, p. 26). In this territorially based view, the value proposition of culture stands out. The sense of place and cultural assets are the basis for creativity. As Richards \& Wilson (2005, p.7) recognise, 'developing distinctiveness on the basis of intangible culture and creativity requires destinations to establish a link in the mind of the visitor between particular manifestations of culture and creativity and specific locations'. Regions must produce their own cultural symbols (ibid.). Taking that into account, cultural mapping, drawing connections between people and places, is a tool, a methodology, and a process at creativity's service.

Cultural mapping, in the creative tourism context, is a means towards sustainability and local development. Regional cultural resources and community engagement are sources of development and financial income to the local. Mapping cannot be done without involving communities: the patrimonial value of intangible heritage cannot be a mere part of the political and ideological rhetoric or an external desperate attempt to avoid the extinction of certain cultural expressions (Cabeça, 2016). Heritage bearers, as the practitioners and rulers of their cultural forms (ibid.), are a key element in creative tourism and must have an active role in the development of creative tourism experiences (providing the experiences to visitors) and in cultural mapping (determining what best describes their regions).

Given these findings, creative tourism can contribute to the 2030 Agenda for Sustainable Development (https://sustainabledevelopment.un.org), promoting 'sustained, inclusive and sustainable economic growth', reducing inequality within the country, making sustainable places, ensuring 'sustainable consumption and production patterns', and promoting a sustainable use of terrestrial ecosystems, amongst other gains. In fact, creative tourism can be seen as a tool for local empowerment, as Miettinen's (2005) case studies on local crafts communities prove. There are sustainable manners of involving visitors and communities in a learning experience, achieving economic benefits for local communities and increasing the visitor's satisfaction in knowing more about the culture they emerge into (ibid.).

\section{Aknowlegment}

CREATOUR (project no 16437) is funded under the Joint Activities Programme of PORTUGAL 2020, by COMPETE2020, POR Lisboa, POR Algarve and Fundação para a Ciência e Tecnologia.

\section{References}

Aitken, S., Craine, J. (2006). Guest Editorial: Affective Geovisualizations. Retrieved November 27, 2017, from https://www.directionsmag.com/article/3015

Anderson, K. \& Smith, S. J. (2001). Editorial: Emotional geographies. Transactions of the Institute of British Geographers, 26(1), 7-10.
Austin, D. (1994). Incorporating cognitive theory into environmental policy making. The Environmental Professional, 16(3), 262-274.

Barata, F. T., Molinari, F., Marsh, J. \& Cabeça, S. M. (Eds.). (2017). Creative Innovation and Related Living Lab Experiences: a Mediterranean Model. Évora: Cátedra UNESCO.

Buhalis, D. (2000). Marketing the competitive destination of the future. Tourism Management, 21(1), 97-116.

Cabeça, S. M. (2016). Estrutura e processo de formação das formas culturais: o caso do Cante Alentejano, Évora: Cátedra UNESCO.

Caquard, S. \& Cartwright, W. (2014). Narrative Cartography: From Mapping Stories to the Narrative of Maps and Mapping. The Cartographic Journal, 51(2), 101-106.

Casey, E. S. (2009). Getting back into place: toward a renewed understanding of the place-world. Indiana University Press.

Casey, W. (1996). How to get from space to place in a fairly short stretch of time. In K. Feld, S; Basso (Ed.), Senses of place (pp. 13-52). Santa Fe: School of American Research Press.

Cattoor, B. \& Perkins, C. (2014). Re-cartographies of Landscape: New Narratives in Architectural Atlases. The Cartographic Journal, 51(2), 166-178.

Cauchi-Santoro, R. (2016). Mapping community identity: Safeguarding the memories of a city's downtown core. City, Culture and Society, 7(1), 43-54.

Chua, A., Servillo, L., Marcheggiani, E. \& Moere, A. Vande. (2016). Mapping Cilento: Using geotagged social media data to characterize tourist flows in southern Italy. Tourism Management, 57, 295-310.

Cosgrove, D. (2005). Mapping / Cartography. In Sibley et all. (Ed.), Cultural geography: a critical dictionary of key concepts (pp. 27-33). London: I.B. Tauris.

Craine, J. \& Aitken, S. C. (2009). The emotional life of maps and other visual geographies. Rethinking Maps: New Frontiers in Cartographic Theory, 28, 149.

Crang, M. (1997). Picturing practices: research through the tourist gaze. Progress in Human Geography, 21(3), 359-373.

D'Angella, F. \& Go, F. M. (2009). Tale of two cities' collaborative tourism marketing: Towards a theory of destination stakeholder assessment. Tourism Management, 30(3), 429-440.

Duxbury, N., Garrett-Petts, W. F. \& Maclennan, D. (2015). Cultural Mapping as Cultural Inquiry. Introduction to an Emerging Field of Practice. In Cultural Mapping as Cultural Inquiry, 1-44.

Eräranta, K., Leino, T., Seppälä, T., Viña, S. \& Timonen, E. (2016). Mapping the Pig Tale Journey: A multidisciplinary design framework for cultural mapping in an old abattoir. City, Culture and Society, 7(1), 25-33.

Farías, I. (2011). Tourist Maps as Diagrams of Destination Space. Space and Culture, 14(4), 398-414.

Freitas, R. (2016). Cultural mapping as a development tool. City, Culture and Society, 7(1), 9-16.

Gonçalves, A. R. (2008). As Comunidades Criativas, o Turismo e a Cultura. Revista Dos Algarves, 17, 10-18

Goodchild, M. F. (2007). Citizens as sensors: the world of volunteered geography. GeoJournal, 69(4), 211-221.

Graybill, J. K. (2013). Mapping an emotional topography of an ecological homeland: The case of Sakhalin Island, Russia. Emotion, Space and Society, 8(1), 39-50.

Gu, H \& Ryan, C. (2008). Place attachment, identity and community impacts of tourism-the case of a Beijing hutong. Tourism Management, 29(4), 637-647.

Guerreiro, A. \& Marques, J. F. (2017). Visita Guiada à Fábrica de Antiguidades: Sociologia, Turismo e Autenticidade. Anais Brasileiros de Estudos Turísticos 7(1), 8 - 22

Ilincic, M. (2013). Benefits of Creative Tourism - The Tourist Perspective. In Expert Meeting on Alternative and Creative tourism in cities ( $\mathrm{p}$. Barcelona).

Jeannotte, M. S. (2016). Story-telling about place: Engaging citizens in 
cultural mapping. City, Culture and Society, 7(1), 35-41.

Jensen, R. (1999). The dream society: how the coming shift from information to imagination will transform your business. McGraw-Hill.

Kitchin, R. (2010). Post-representational cartography. Lo Squaderno, Explorations in Space and Society, (15), 7-12.

Kitchin, R., Gleeson, J. \& Dodge, M. (2013). Unfolding mapping practices: a new epistemology for cartography. Transactions of the Institute of British Geographers, 38(3), 480-496.

Klettner, S., Huang, H., Schmidt, M. \& Gartner, G. (2013). Crowdsourcing affective responses to space. Kartographische Nachrichten.

Longley, A. \& Duxbury, N. (2016). Introduction: Mapping cultural intangibles. City, Culture and Society, 7(1), 1-7.

Lydon, M. (2003). Community mapping: The recovery (and discovery) of our common ground. Geomatica, 57(2), 131-143.

Marx, K. (1975). O Capital, 3a ed., Lisboa: Edições 70.

Mauss, M. (1971). Sociologia y Antropologia, Madrid: Editorial Tecnos. Mauss, M. (1988). Ensaio sobre a Dádiva, Lisboa: Edições 70.

Miettinen, S. (2005). Creative tourism as tool for local empowerment. In G. Richards e J. Wilson, From Cultural Tourism to Creative Tourism. Part 4 - Changing Experiences - the development of Creative Tourism, ATLAS. 53-63.

Offen, K. H. (2003). Narrating place and identity, or mapping Miskitu land claims in northeastern Nicaragua. Human Organization, 62(4), 382-392.

Ohridska-Olson, R. \& Ivanov, S. (2010). Creative Tourism Business Model and its Application in Bulgaria. In Proceedings of the Black Sea Tourism Forum 'Cultural Tourism - The Future of Bulgaria.

Ortega Nuere, C. \& Bayón, F. (2015). Cultural Mapping and Urban Regeneration: Analyzing Emergent Narratives about Bilbao. Culture and Local Governance, 5(1-2), 9.

Pánek, J. \& Benediktsson, K. (2017). Emotional mapping and its participatory potential: Opinions about cycling conditions in Reykjavík, Iceland. Cities, 61, 65-73.

Parker, B. (2006). Constructing community through maps? Power and praxis in community mapping. Professional Geographer, 58(4), 470484.

Pearce, M. W. (2014). The Last Piece Is You. The Cartographic Journal, 51(2), 107-122.

Perkins, C. (2007). Community Mapping. The Cartographic Journal, 44(2), 127-137.

Perkins, C. (2009). Performative and Embodied Mapping. In International Encyclopedia of Human Geography (pp. 126-132). Elsevier.

Pillai, J. (2013). Cultural mapping: a guide to understanding place, community, and continuity.

Radović, D. (2016). Measuring the non-measurable: On mapping subjectivities in urban research. City, Culture and Society, 7(1), 17-24.

Reuschel, A-K.W., Piatti, B. \& Hurni, L. (2014). Data-driven Expansion of Dense Regions - A Cartographic Approach in Literary Geography. The Cartographic Journal, 51(2), 123-140.

Richards, G. \& Raymond, C. (2000). Creative Tourism. ATLAS News, 23, $16-20$.

Richards, G. \& Wilson, J. (2005). Changing Places - the spatial challenge of creativity. In G. Richards e J. Wilson, From Cultural Tourism to Creative Tourism. Part 3 - Changing Places - the spatial challenge of creativity, ATLAS. 7-8

Richards, G. (2011). Creativity and tourism. The state of the art. Annals of Tourism Research.

Richards, G. (2016). The challenge of creative tourism. Ethnologies, 38, $1-2,31-42$.

Roberts, L. (2014). The Bulger Case: A Spatial Story. The Cartographic Journal, 51(2), 141-151.
Simpson, M. C. (2008). Community Benefit Tourism Initiatives-A conceptual oxymoron? Tourism Management, 29(1), 1-18.

Stewart, S. (2007). Cultural Mapping Toolkit. (C. C. N. of C. and 2010 L. Now, Ed.). Vancouver.

Straumann, R. K., Çöltekin, A. \& Andrienko, G. (2014). Towards (Re)Constructing Narratives from Georeferenced Photographs through Visual Analytics. The Cartographic Journal, 51(2), 152-165.

UNESCO (2006). Towards Sustainable Strategies for Creative Tourism: discussion report of the planning meeting for the 2008 International Conference on Creative Tourism.

Received: 28.09 .2018

Revisions required: 30.11 .2018

Accepted: 12.01.2019 